\title{
Leptobacterium flavescens gen. nov., sp. nov., a marine member of the family Flavobacteriaceae, isolated from marine sponge and seawater
}

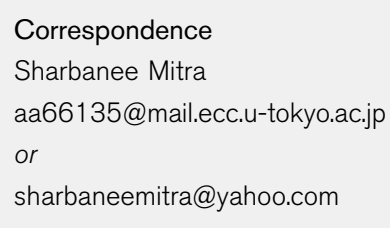

The family Flavobacteriaceae belongs to the phylum Bacteroidetes (Ludwig \& Klenk, 2001), which accounts for almost one-third of marine bacteria (Pinhassi et al., 2006). Briefly outlined by Reichenbach (1989), the description of the family Flavobacteriaceae was completed and emended by Bernardet et al. (1996, 2002). Members of the family have given rise to extensive research owing to the diversity of their ecological niches and physiological characteristics and also to the fact that some of them may cause disease in humans and various animal species (Bernardet \& Nakagawa, 2006).

In the present study, we attempted to elucidate the taxonomic positions of strains YM3-301 ${ }^{\mathrm{T}}$, HG868, 04PA2 Co4-8B, 04PA2 Co4-99A, 04PA2 018SW-3 and 04PA2

The GenBank/EMBL/DDBJ accession numbers for the 16S rRNA gene sequences of strains $\mathrm{YM}-301^{\top}$, 04PA2 018SW-18, 04PA2 018SW-3, HG868, 04PA2 Co4-8B and 04PA2 Co4-99A are AB362212, AB362213, AB362214, AB362215, AB362216 and AB362217, respectively.

A transmission electron micrograph of a cell of strain $\mathrm{YM} 3-301^{\top}$ is presented as a supplementary figure available with the online version of this paper.
018SW-18 by using a polyphasic taxonomic approach that included 16S rRNA gene sequence analysis and physiological, biochemical and chemotaxonomic investigations. On the basis of these data, we suggest that the isolates represent a novel genus and species of the family Flavobacteriaceae, phylum Bacteroidetes.

All of the strains were isolated from specimens collected in the Republic of Palau, located in the Pacific Ocean, close to the Philippines (almost $1000 \mathrm{~km}$ from Mindanao Island, the Philippines). The source of strain YM03-301 ${ }^{\mathrm{T}}$ was a marine sponge - identified as Clathria (Microciona) eurypa (de Laubenfels) - collected at Iwayama Bay on Koror Island in December 2002. All of the other strains were isolated from specimens collected in September 2004. Strain HG868 was isolated from an unidentified marine sponge collected on the shore of Angaur Island (GPS location, $06^{\circ} 53^{\prime} 33.0^{\prime \prime} \mathrm{N}$ $134^{\circ} 8^{\prime} 21.4^{\prime \prime} \mathrm{E}$ ). The four 04PA2 strains were isolated from the hard coral Galaxea fascicularis Linnaeus 1767 and from seawater collected at the coral reef in the south-west of Malakal Bay on Malakal Island in the Republic of Palau (depth, 5 m; GPS location, $07^{\circ} 18^{\prime} \quad 1.6^{\prime \prime} \mathrm{N} 134^{\circ} 27^{\prime} 21.5^{\prime \prime} \mathrm{E}$ ). 
Strains 04PA2 018SW-3 and 04PA2 018SW-18 were isolated from seawater kept for $2-5 \mathrm{~h}$ in a $500 \mathrm{ml}$ plastic bottle with the hard coral; strains 04PA2 Co4-8B and 04PA2 Co4-99A were isolated from a piece of hard coral. For strains 04PA2 018SW-3 and 04PA2 018SW-18, $50 \mu \mathrm{l}$ seawater was spread onto marine agar 2216 (MA; Difco). The sponge and hardcoral specimens $\left(0.5-1 \mathrm{~cm}^{3}\right)$ were homogenized with a glass rod in $5 \mathrm{ml}$ sterile seawater. For strain YM3-301 ${ }^{\mathrm{T}}, 50 \mu \mathrm{l}$ homogenate was spread onto medium $\mathrm{P}$ (Yoon et al., 2007). For isolation of strain HG868, the 1/100-diluted homogenate $(50 \mu \mathrm{l})$ was spread onto MA diluted to $1 / 100$ with $70 \%$ seawater. For strain 04PA2 Co4-8B, $50 \mu \mathrm{l}$ homogenate was diluted to $1 / 10$ and spread onto MA. For strain 04PA2 Co4$99 \mathrm{~A}$, the 1/100-diluted homogenate was spread onto MA containing $1 \% \mathrm{CaCO}_{3}$. After cultivation at $25{ }^{\circ} \mathrm{C}$ for more than 30 days, colonies were picked and then re-isolated on MA.

Growth at different temperatures and $\mathrm{pH}$ values was tested at $17-35{ }^{\circ} \mathrm{C}$ (using increments of $5{ }^{\circ} \mathrm{C}$ ) on MA and at $\mathrm{pH} 6-$ 9 (using increments of one $\mathrm{pH}$ unit) in marine broth (Difco), respectively. The $\mathrm{pH}$ of the marine broth was adjusted with $\mathrm{NaOH}$ and $\mathrm{HCl}$ prior to autoclaving and was verified after autoclaving. The $\mathrm{NaCl}$ concentrations for growth were determined using a salt-tolerance test medium containing $1 \%$ tryptone, $0.3 \%$ yeast extract, $0.9 \%$ $\mathrm{MgCl}_{2} \cdot 6 \mathrm{H}_{2} \mathrm{O}, 0.9 \% \mathrm{MgSO}_{4} \cdot 7 \mathrm{H}_{2} \mathrm{O}, 0.2 \% \mathrm{CaCl}_{2} \cdot 2 \mathrm{H}_{2} \mathrm{O}$, $0.06 \% \mathrm{KCl}$ and $1.5 \%$ agar, with $0-10 \%$ (w/v) NaCl. Gramstaining was performed using the BD Gram-staining kit (Becton Dickinson). Cell morphology was observed using transmission electron microscopy (see Supplementary Fig. S1, available in IJSEM Online). For transmission electron microscopy, cells were mounted on Formvar-coated copper grids and negatively stained with $1 \%(\mathrm{w} / \mathrm{v})$ aqueous uranyl acetate. Grids were observed in a JEOL 1010 transmission electron microscope operated at $100 \mathrm{kV}$. Gliding motility was observed by means of phase-contrast microscopy (BX60; Olympus) of marine broth cultures (Bernardet et al., 2002). Growth under anaerobic conditions was determined after 2 weeks incubation in an AnaeroPack (Mitsubishi Gas Chemical) on MA. Catalase and oxidase activities were determined by testing bubble formation in a $3 \% \mathrm{H}_{2} \mathrm{O}_{2}$ solution and using cytochrome oxidase paper (Nissui Pharmaceutical), respectively. The presence of flexirubin pigments was investigated by observing the colour shift of the cell mass after exposure to a $20 \%(\mathrm{w} / \mathrm{v}) \mathrm{KOH}$ solution (Reichenbach, 1989; Bernardet et al., 2002). API commercial strips (bioMérieux) were used to determine physiological and biochemical characteristics of the novel strains. All of the suspension media used with the API test strips were supplemented with $\mathrm{NaCl}$ to a final concentration of $0.85 \%(\mathrm{w} / \mathrm{v}) \mathrm{NaCl}$. API 20E, API ZYM and API $50 \mathrm{CH}$ strips were incubated for $24 \mathrm{~h}$ at $30^{\circ} \mathrm{C}, 4 \mathrm{~h}$ at $37^{\circ} \mathrm{C}$ and $48 \mathrm{~h}$ at $25^{\circ} \mathrm{C}$, respectively.

The respiratory quinone system and the cellular fatty acid content were determined as described by Xie \& Yokota (2003). For the fatty acid analysis, strains were grown on MA for $24 \mathrm{~h}$ and analysed using the MIDI Microbial
Identification System. The major quinone in the novel strains was MK-6 and the major cellular fatty acids were. The major fatty acids $(>5.0 \%)$ for strain $\mathrm{YM} 3-301^{\mathrm{T}}$ were i15: 0 (22.7\%), i15:1 (14.5\%), i17:0 3-OH (11.7\%), unknown (equivalent chain-length, 13.562) (10.8\%), i16:0 $3-\mathrm{OH}(6.8 \%)$ and i15:0 3-OH (6.6\%) (Table 1).

DNA was extracted using the method of Marmur (1961) from cells grown on MA and the DNA G $+\mathrm{C}$ content was determined with the HPLC method of Mesbah et al. (1989). The DNA G + C contents of the six isolates were in the range $41.8-43.5 \mathrm{~mol} \%$.

An approximately $1500 \mathrm{bp}$ fragment of the 16S rRNA gene was amplified from the extracted DNA by using bacterial universal primers specific to the $16 \mathrm{~S}$ rRNA gene: primer $9 \mathrm{~F}$ (5'-GAGTTTGATCCTGGCTCAG-3'; positions 8-27, according to the Escherichia coli numbering system of Brosius et al., 1978) and primer 1510R (5'-GGCTACCTTGTTACGTA-3'; positions 1510-1527). The PCR and sequencing protocols have been described previously (Xie \& Yokota, 2003). DNA-DNA hybridization between the six isolates was carried out with photobiotin-labelled probes in microplate wells as described by Ezaki et al. (1989). The hybridization temperature was $42{ }^{\circ} \mathrm{C}$.

To determine the phylogenetic positions of the strains, their 16S rRNA gene sequences were compared with sequences obtained from GenBank. Multiple alignments of the sequences were performed using CLUSTAL_X, version 1.83 (Thompson et al., 1997). Alignment gaps and ambiguous bases were not taken into consideration in the comparison of 1174 bases of the $16 \mathrm{~S}$ rRNA gene sequence. Phylogenetic relationships were analysed using the same software. Distances were calculated using the Kimura two-parameter model (Kimura, 1980). Clustering based on the neighbour-joining method (Saitou \& Nei, 1987) was determined using bootstrap percentages based on 1000 replications (Felsenstein, 1985) (Fig. 1). Similarity values were calculated using MEGA3.1 (Kumar et al., 2004).

The phylogenetic analysis based on 16S rRNA gene sequences revealed that strains YM3-301 ${ }^{\mathrm{T}}$, HG868, 04PA2 Co4-8B, 04PA2 Co4-99A, 04PA2 018SW-3 and 04PA2 018SW-18 formed a distinct lineage within the family Flavobacteriaceae, showing the highest sequence similarity (90.3-90.5\%) with respect to members of the genus Leeuwenhoekiella (Nedashkovskaya et al., 2005); the similarities with respect to the type strain of Zhouia amylolytica (Liu et al., 2006) were $90.8-90.9 \%$ and those for members of other genera in the family were $86.3-89.1 \%$. In contrast, the novel isolates shared high levels of $16 \mathrm{~S}$ rRNA gene sequence similarity (99.7-100\%) and DNA-DNA relatedness (72$94 \%$ ) with each other. Hence, they represent a new genus and novel species in the family Flavobacteriaceae.

The phenotypic characteristics shared by strains $\mathrm{YM} 3-301^{\mathrm{T}}$, HG868, 04PA2 Co4-8B, 04PA2 Co4-99A, 04PA2 018SW-3 and $04 \mathrm{PA} 2018 \mathrm{SW}-18$ are listed in the genus and species descriptions, while those that serve to distinguish them from 
Table 1. Cellular fatty acid contents (\%) of the novel strains and of related taxa in the family Flavobacteriaceae

Taxa: 1, YM3-301 ${ }^{\mathrm{T}}$; 2, HG868; 3, 04PA2 Co4-8B; 4, 04PA2 Co4-99A; 5, 04PA2 018SW-3; 6, 04PA2 018SW-18; 7, Leeuwenhoekiella (three species; Nedashkovskaya et al., 2005); 8, Croceibacter atlanticus HTCC $2559^{\mathrm{T}}$ (Cho \& Giovannoni, 2003); 9, Vitellibacter vladivostokensis KMM $3516^{\mathrm{T}}$ (Nedashkovskaya et al., 2003); 10, Aequorivita (four species; Bowman \& Nichols, 2002); 11, Sediminicola luteus LMG 23246 ${ }^{\mathrm{T}}$ (Khan et al., 2006); 12, Cellulophaga (six species; Bowman, 2000). Fatty acids amounting to less than $1 \%$ of the total fatty acids in all strains listed are not shown. Some of the taxa were not cultivated under the same conditions. tr, Trace amount $(<0.5 \%)$; , not detected.

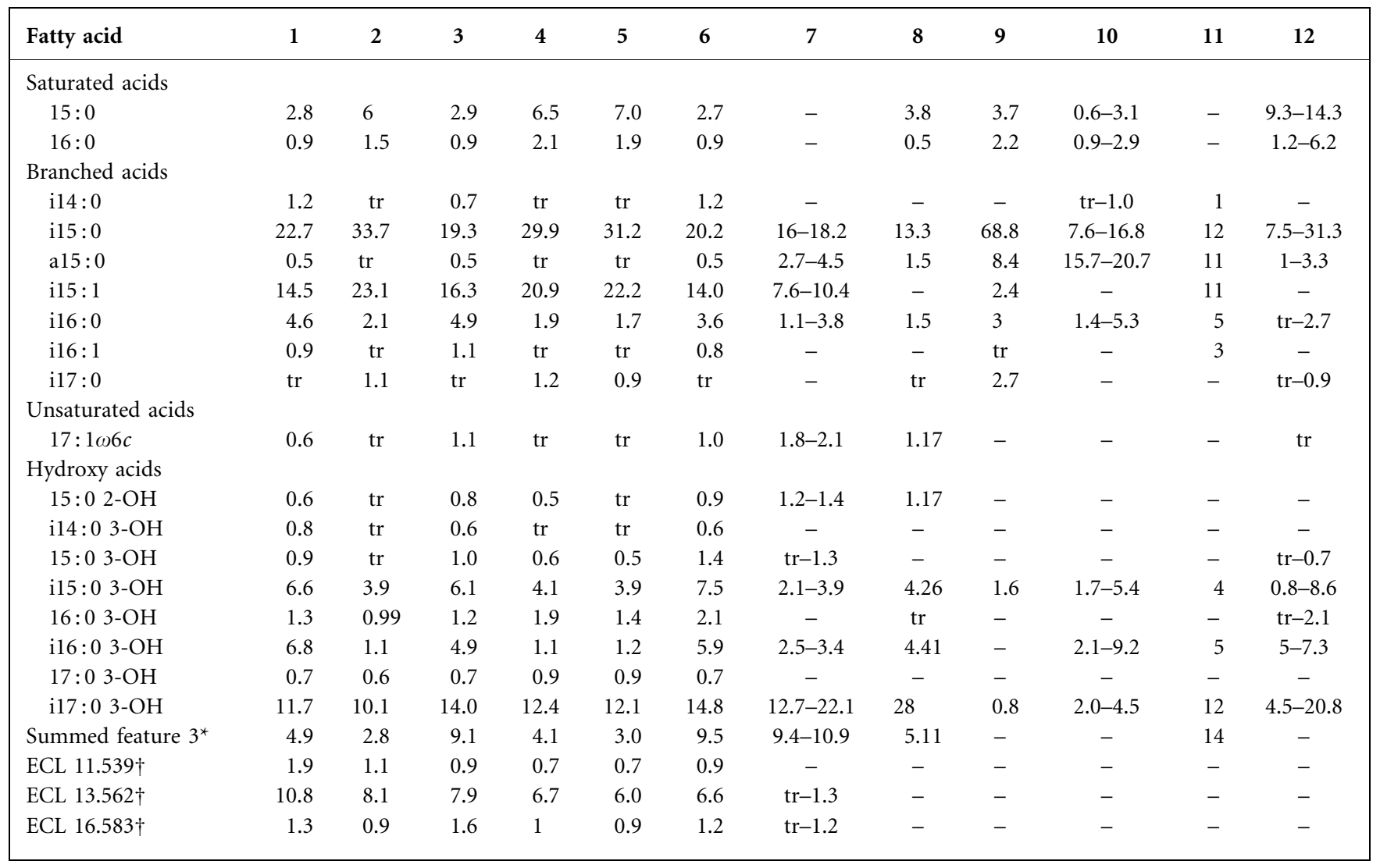

${ }^{*}$ Summed features consist of one or more fatty acids that could not be separated by the Microbial Identification system. Summed feature 3 comprised $16: 1 \omega 7 c$ and/or i15:0 2-OH.

$\dagger$ Unidentified fatty acids (ECL, equivalent chain-length).

their closest relatives are listed in Table 2. In particular, the six isolates were characterized by their inability to grow at $0-4{ }^{\circ} \mathrm{C}$ and with $>4 \% \mathrm{NaCl}$ (although they required at least $1 \%$ $\mathrm{NaCl}$ for growth), by their inability to move over surfaces by gliding and by the high $\mathrm{G}+\mathrm{C}$ content of their DNA.

On the basis of the phylogenetic, physiological and biochemical data for strains YM3-301 ${ }^{\mathrm{T}}$, HG868, 04PA2 Co4-8B, 04PA2 Co4-99A, 04PA2 018SW-3 and 04PA2 $018 \mathrm{SW}-18$, it is concluded that they represent a novel species in a new genus belonging to the family Flavobacteriaceae, for which the name Leptobacterium flavescens gen. nov., sp. nov. is proposed.

\section{Description of Leptobacterium gen. nov.}

Leptobacterium (Lep.to.bac.te'ri.um. Gr. adj. leptos thin, fine, narrow; L. neut. n. bacterium rod; N.L. neut. n. Leptobacterium a slender rod).
Cells are straight, non-gliding rods. Gram-negative. Strictly aerobic. Cells are devoid of flagella and endospores are not formed. Flexirubin pigments are not produced. Catalaseand oxidase-positive. Nitrate and nitrite are not reduced. The major respiratory quinone is MK- 6 . The DNA G + C content of the type species is $42-44 \%$. The major cellular fatty acids are i15:0, i15:1 and i17:0 3-OH. The type species is Leptobacterium flavescens.

\section{Description of Leptobacterium flavescens sp. nov.}

Leptobacterium flavescens (fla.ves'cens. L. part. adj. flavescens becoming golden-yellow).

The main characteristics are the same as those given for the genus. In addition, cells are approximately $0.5-0.6 \mu \mathrm{m}$ wide and 8.5-9.0 $\mu \mathrm{m}$ long. Colonies on MA are circular, 


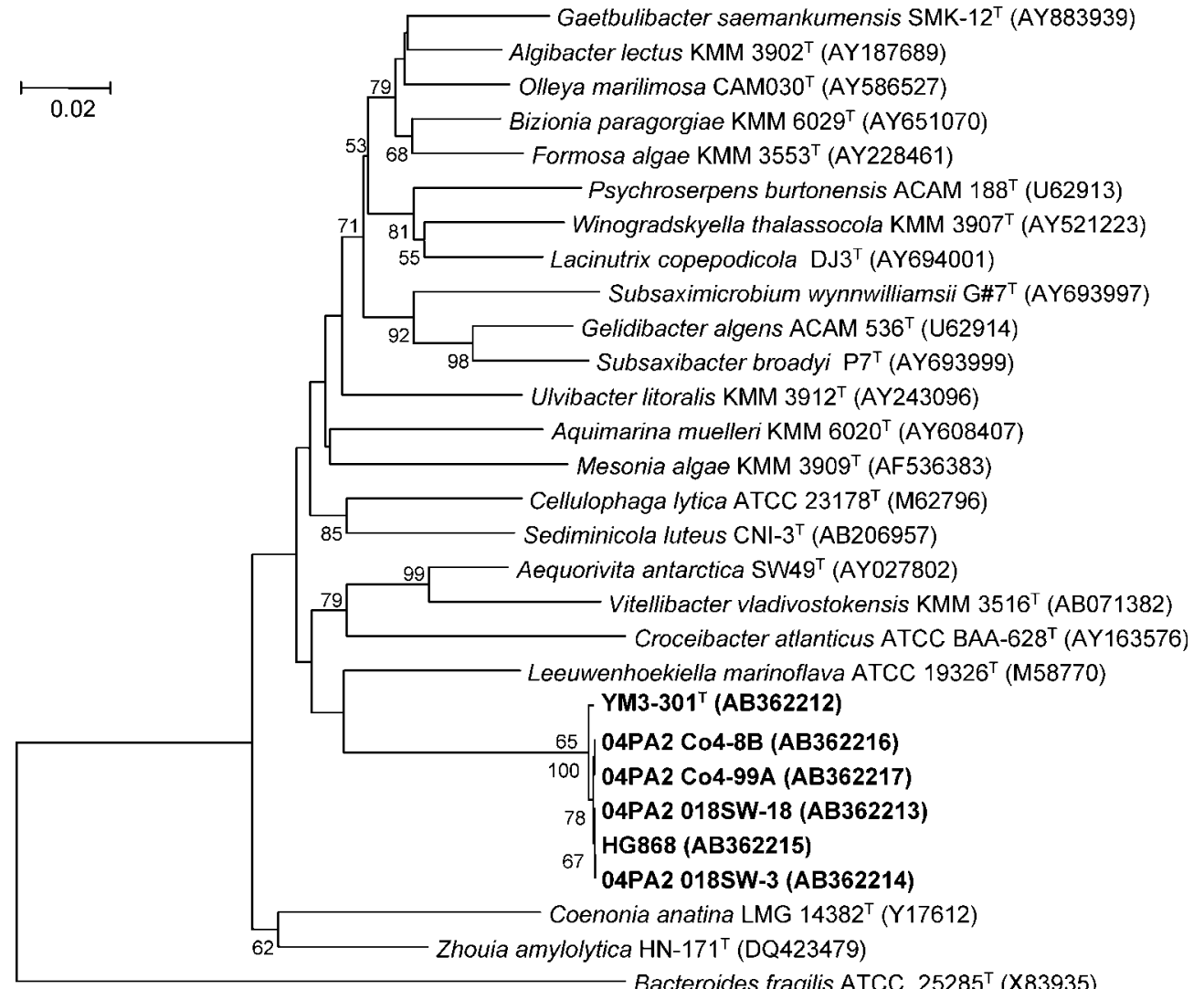

Fig. 1. Neighbour-joining phylogenetic tree, based on 16S rRNA gene sequences, showing the phylogenetic position of strains YM3-301 ${ }^{\top}$, HG868, 04PA2 Co4-8B, 04PA2 Co4-99A, 04PA2 018SW-3 and 04PA2 018SW-18, representatives of closely related genera and other genera of the family Flavobacteriaceae. The tree was rooted using Bacteroides fragilis ATCC $25285^{\top}$ (X83935) as an outgroup. Numbers at nodes indicate bootstrap percentages (based on 1000 trees); only values greater than $50 \%$ are shown. Bar, $2 \%$ sequence divergence.

flat with entire edges and pale-yellow-pigmented. Growth occurs at $17-30{ }^{\circ} \mathrm{C}$ (optimally at $25-30{ }^{\circ} \mathrm{C}$ ). No growth occurs at 4 or $45{ }^{\circ} \mathrm{C}$. The $\mathrm{pH}$ range for growth is 6-9 (optimum, around $\mathrm{pH} 6-7$ ). $\mathrm{NaCl}$ is required for growth and can be tolerated up to $4 \%(\mathrm{w} / \mathrm{v})$. In API $20 \mathrm{E}$ strips, gelatin and tryptophan are hydrolysed, but tests for the Voges-Proskauer reaction, citrate utilization, urea hydrolysis and the production of ONPG, arginine dihydrolase, lysine decarboxylase, ornithine decarboxylase, hydrogen sulfide and indole give negative results. In API $50 \mathrm{CH}$ strips, acid is produced from aesculin-ferric citrate, maltose, 5-ketogluconate and D-arabinose, but not from $\mathrm{L}$-arabinose, $\mathrm{D}$-xylose, $\mathrm{L}$-xylose, methyl $\beta$-D-xylopyranoside, galactose, glucose, fructose, ribose, mannose, rhamnose, methyl $\alpha$-D-mannopyranoside, methyl $\alpha$-D-glucopyranoside, $\mathrm{N}$-acetylglucosamine, amygdalin, arbutin, salicin, cellobiose, lactose, melibiose, sucrose, trehalose, melezitose, inulin, raffinose, gentiobiose, turanose, D-lyxose, D-tagatose, D-fucose, L-fucose, glycerol, erythritol, adonitol, sorbose, dulcitol, inositol, mannitol, sorbitol, starch, glycogen, xylitol, D-arabitol, L-arabitol, gluconate or 2- ketogluconate. In API ZYM strips, alkaline phosphatase, leucine arylamidase, valine arylamidase, trypsin, $\alpha$-chymotrypsin, acid phosphatase, naphthol phosphohydrolase and $N$-acetyl- $\beta$-glucosaminidase activities are present, but esterase, esterase lipase, $\beta$-glucuronidase, cystine arylamidase, $\alpha$-galactosidase, $\beta$-galactosidase, naphthol-AS-BIphosphohydrolase, $\alpha$-glucuronidase, $\alpha$-mannosidase, $\alpha$ glucosidase and $\beta$-glucosidase activities are absent. The major fatty acids are i15:0, i15:1 and i17:0 3-OH.

The type strain, YM3-301 ${ }^{\mathrm{T}} \quad\left(=\mathrm{KCTC} 22160^{\mathrm{T}}=\mathrm{MBIC}\right.$ $06275^{\mathrm{T}}=$ NBRC $\left.104141^{\mathrm{T}}\right)$, was isolated from a marine sponge Clathria (Microciona) eurypa collected at Iwayama Bay on Koror Island, Republic of Palau. The DNA G + C content of the type strain is $42 \mathrm{~mol} \%$.

\section{Acknowledgements}

We are grateful to Professor Patricia R. Bergquist at the University of Auckland in New Zealand for identifying the marine sponges. We also thank Dr Hideki Yukihira at the Palau International Coral Reef Center (Koror, Republic of Palau) for his help with the collection and 
Table 2. Differential characteristics of the novel strains and related taxa in the family Flavobacteriaceae

Taxa: 1, Leptobacterium flavescens sp. nov. (six strains); 2, Leeuwenhoekiella (three species; Nedashkovskaya et al., 2005); 3, Croceibacter atlanticus HTCC $2559^{\mathrm{T}}$ (Cho \& Giovannoni, 2003); 4, V. vladivostokensis KMM 3516 ${ }^{\mathrm{T}}$ (Nedashkovskaya et al., 2003); 5, Aequorivita (four species; Bowman \& Nichols, 2002); 6, S. luteus LMG 23246 ${ }^{\mathrm{T}}$ (Khan et al., 2006); 7, Cellulophaga (six species; Johansen et al., 1999; Bowman, 2000). +, Positive; -, negative; $\mathrm{W}$, weakly positive; $\mathrm{V}$, variable, ND, no data available; $\mathrm{M}$, marine environment; MP, marine sponge; MS, marine sediment; QSS, quartz-stone subliths; SC, sea cucumber; SI, sea ice; SW, seawater; BO, bright orange; $\mathrm{NY}$, non-diffusible yellow; NY-O, non-diffusible yellow-orange; O-Y, orangeyellow; y, yellow.

\begin{tabular}{|c|c|c|c|c|c|c|c|}
\hline Characteristic & 1 & 2 & 3 & 4 & 5 & 6 & 7 \\
\hline Gliding motility & - & + & - & - & - & - & + \\
\hline Flexirubin & - & $\mathrm{v}$ & - & + & - & - & - \\
\hline $\mathrm{NaCl}$ requirement & + & - & + & + & $\mathrm{V}$ & ND & + \\
\hline $30{ }^{\circ} \mathrm{C}$ & + & + & - & + & - & + & + \\
\hline $15 \% \mathrm{NaCl}$ & - & + & + & - & - & - & - \\
\hline Oxidase & + & + & - & + & - & + & + \\
\hline Catalase & + & + & + & + & + & $\mathrm{w}$ & + \\
\hline Nitrate reduction & - & - & - & - & - & + & - \\
\hline \multicolumn{8}{|l|}{ Hydrolysis of: } \\
\hline Aesculin & + & - & $\mathrm{ND}$ & ND & + & $\mathrm{ND}$ & ND \\
\hline Maltose & + & - & - & - & $\mathrm{ND}$ & + & + \\
\hline DNA G $+C$ content $(\mathrm{mol} \%)$ & $41.8-43.5$ & $35-38$ & 35 & 41.3 & $33-39$ & $38-40$ & $32-34$ \\
\hline
\end{tabular}

identification of the hard coral. This work was supported by the New Energy and Industrial Technology Development Organization (NEDO).

\section{References}

Bernardet, J.-F. \& Nakagawa, Y. (2006). An introduction to the family Flavobacteriaceae. In The Prokaryotes: a Handbook on the Biology of Bacteria, 3rd edn, vol. 7, pp. 455-480. Edited by M. Dworkin, S. Falkow, E. Rosenberg, K.-H. Schleifer \& E. Stackebrandt. New York: Springer.

Bernardet, J.-F., Segers, P., Vancanneyt, M., Berthe, F., Kersters, K. \& Vandamme, P. (1996). Cutting a Gordian knot: emended classification and description of the genus Flavobacterium, emended description of the family Flavobacteriaceae, and proposal of Flavobacterium hydatis nom. nov. (basonym, Cytophaga aquatilis Strohl and Tait 1978). Int J Syst Bacteriol 46, 128-148.

Bernardet, J.-F., Nakagawa, Y. \& Holmes, B. (2002). Proposed minimal standards for describing new taxa of the family Flavobacteriaceae and emended description of the family. Int J Syst Evol Microbiol 52, 1049-1070.

Bowman, J. P. (2000). Description of Cellulophaga algicola sp. nov., isolated from the surfaces of Antarctic algae, and reclassification of Cytophaga uliginosa (ZoBell and Upham 1944) Reichenbach 1989 as Cellulophaga uliginosa comb. nov. Int J Syst Evol Microbiol 50, 18611868.

Bowman, J. P. \& Nichols, D. S. (2002). Aequorivita gen. nov., a member of the family Flavobacteriaceae isolated from terrestrial and marine Antarctic habitats. Int J Syst Evol Microbiol 52, 1533-1541.
Brosius, J., Palmer, M. L., Kennedy, P. J. \& Noller, H. F. (1978). Complete nucleotide sequence of a $16 \mathrm{~S}$ ribosomal RNA gene from Escherichia coli. Proc Natl Acad Sci U S A 75, 4801-4805.

Cho, J.-C. \& Giovannoni, S. J. (2003). Croceibacter atlanticus gen. nov., sp. nov., a novel marine bacterium in the family Flavobacteriaceae. Syst Appl Microbiol 26, 76-83.

Ezaki, T., Hashimoto, Y. \& Yabuuchi, E. (1989). Fluorometric deoxyribonucleic acid-deoxyribonucleic acid hybridization in microdilution wells as an alternative to membrane filter hybridization in which radioisotopes are used to determine genetic relatedness among bacterial strains. Int J Syst Bacteriol 39, 224-229.

Felsenstein, J. (1985). Confidence limits on phylogenies: an approach using the bootstrap. Evolution 39, 783-791.

Johansen, J. E., Nielsen, P. \& Sjøholm, C. (1999). Description of Cellulophaga baltica gen. nov., sp. nov. and Cellulophaga fucicola gen. nov., sp. nov. and reclassification of [Cytophaga] lytica to Cellulophaga lytica gen. nov., comb. nov. Int J Syst Bacteriol 49, 12311240.

Khan, S. T., Nakagawa, Y. \& Harayama, S. (2006). Sediminicola luteus gen. nov., sp. nov., a novel member of the family Flavobacteriaceae. Int J Syst Evol Microbiol 56, 841-845.

Kimura, M. (1980). A simple method for estimating evolutionary rates of base substitutions through comparative studies of nucleotide sequences. J Mol Evol 16, 111-120.

Kumar, S., Tamura, K. \& Nei, M. (2004). MEGA3: integrated software for molecular evolutionary genetics analysis and sequence alignment. Brief Bioinform 5, 150-163.

Liu, Z.-P., Wang, B.-J., Dai, X., Liu, X.-Y. \& Liu, S.-J. (2006). Zhouia amylolytica gen. nov., sp. nov., a novel member of the family 
Flavobacteriaceae isolated from sediment of the South China Sea. Int $J$ Syst Evol Microbiol 56, 2825-2829.

Ludwig, W. \& Klenk, H.-P. (2001). Overview: a phylogenetic backbone and taxonomic framework for prokaryotic systematics. In Bergey's Manual of Systematic Bacteriology, 2nd edn, vol. 1, pp. 49-65. Edited by D. R. Boone, R. W. Castenholz \& G. M, Garrity. New York: Springer.

Marmur, J. (1961). A procedure for the isolation of deoxyribonucleic acid from microorganisms. J Mol Biol 3, 208-218.

Mesbah, M., Premachandran, U. \& Whitman, W. B. (1989). Precise measurement of the $\mathrm{G}+\mathrm{C}$ content of deoxyribonucleic acid by highperformance liquid chromatography. Int J Syst Bacteriol 39, 159-167.

Nedashkovskaya, O. I., Suzuki, M., Vysotskii, M. V. \& Mikhailov, V. V. (2003). Vitellibacter vladivostokensis gen. nov., sp. nov., a new member of the phylum Cytophaga-Flavobacterium-Bacteroides. Int J Syst Evol Microbiol 53, 1281-1286.

Nedashkovskaya, O. I., Vancanneyt, M., Dawyndt, P., Engelbeen, K., Vandemeulebroecke, K., Cleenwerck, I., Hoste, B., Mergaert, J., Tan, T. L. \& other authors (2005). Reclassification of [Cytophaga] marinoflava Reichenbach 1989 as Leeuwenhoekiella marinoflava gen. nov., comb. nov. and description of Leeuwenhoekiella aequorea sp. nov. Int J Syst Evol Microbiol 55, 1033-1038.
Pinhassi, J., Bowman, J. P., Nedashkovskaya, O. I., Lekunberri, I., Gomez-Consarnau, L. \& Pedrós-Alió, C. (2006). Leeuwenhoekiella blandensis sp. nov., a genome-sequenced marine member of the family Flavobacteriaceae. Int J Syst Evol Microbiol 56, 1489-1493.

Reichenbach, H. (1989). The order Cytophagales Leadbetter 1974, 99 ${ }^{\mathrm{AL}}$. In Bergey's Manual of Systematic Bacteriology, vol. 3, pp. 20112073. Edited by J. T. Staley, M. P. Bryant, N. Pfennig \& J. C. Holt. Baltimore: Williams \& Wilkins.

Saitou, N. \& Nei, M. (1987). The neighbor-joining method: a new method for reconstructing phylogenetic trees. Mol Biol Evol 4, 406-425.

Thompson, J. D., Gibson, T. J., Plewniak, F., Jeanmougin, F. \& Higgins, D. G. (1997). The CLUSTAL_X windows interface: flexible strategies for multiple sequence alignment aided by quality analysis tools. Nucleic Acids Res 25, 4876-4882.

Xie, C. H. \& Yokota, A. (2003). Phylogenetic analysis of Lampropedia hyalina based on the 16S rRNA gene sequence. J Gen Appl Microbiol 49, 345-349.

Yoon, J., Yasumoto-Hirose, M., Matsuo, Y., Nozawa, M., Matsuda, S., Kasai, H. \& Yokota, A. (2007). Pelagicoccus mobilis gen. nov., sp. nov., Pelagicoccus albus sp. nov. and Pelagicoccus litoralis sp. nov., three novel members of subdivision 4 within the phylum 'Verrucomicrobia', isolated from seawater by in situ cultivation. Int J Syst Evol Microbiol 57, 1377-1385. 